\title{
SOME PALÆOLITHIC PITS AND PERIODS IN HERTFORDSHIRE, ETC.
}

\author{
By the Rev. H. G. O. Kendall, M.A., F.S.A.
}

Read at Norwich, March 23rd, 1975.

Coming down out of the Chiltern Hills, the River Mimram runs in a comparatively narrow gorge in a S.E. direction, until it joins the Lea near Hertford. The last-named river pursues a parallel course to the westward, as a consequent stream, but on leaving the Chilterns it runs, still S.E., across a wide subsequent valley. The latter stretches, in a gentle curve, from Hertford on the E. to Rickmansworth, south of which place it debouches on the Thames valley. Down the huge subsequent valley ice must have pushed its way from the Bishop's Stortford and Hitchin gaps, reinforced by minor supplies from the Chilterns. There is boulder clay at Hertford and further west at Hatfield, within the valley. On reaching the southern side of the latter, in Hatfield Park, the Lea is suddenly deflected eastward. The way is barred by the high ground on that bank, capped by tertiary outliers. At Hertford it takes another and sharper turn, due south, to join the Thamcs at London.

Mr. Worthington Smith, in his indefatigable researches, has made discoveries of Palæolithic implements from the source to the mouth of the Lea. Leagrave, the birthplace of the stream; the high ground at Caddington, \&c., to the west; No Man's Land, Wheathampstead, where an ancient tributary once ran, long since dry ; Hertford, Ware, Cheshunt, and Stoke Newington have all been made to yield up their treasures and add to the fascination of that deeply interesting book, "Man, the Primæval Savage." At Welwyn, on the Mimram, or Maran, Mr. Worthington Smith found broken pieces of implements.

I well remember my first introduction to the keen-sighted prehistorian, when he put a fine implement into my hands and told me that he reckoned he had walked 40 miles for every one of those that he obtained. I instantly determined to do better, and began a search of all the pits within reach of my paternal home at Hatfield. I had totalled 50 miles before I found such an one: a black, very slightly abraded tongue-shaped implement in the Workhouse Pit at Welwyn, now done away with to make room for the late Mr. Dering's stupendous undertaking of the "New Road." In the making of the latter some coarse glacial gravels were revealed beneath the old river material.

I obtained some flakes, etc., in situ from the contorted gravel; and implements, fragments, flakes, etc., which had manifestly all fallen from it. They could have come from nowhere but the contorted material with the remains of which they were lying. They are of the Chelles period, and some, perhaps, pre-Chelles. 
The sequence of strata was: surface soil, contorted gravel with clayey matrix, river sand, and gravel, and an older glacial (?) gravel.

From the thin banks of sand and gravel I dug out a well-made implement of almost ovate outline but having a narrow, round-nosed end; a perch-backed implement with square ends and a cutting edge all round; and a large chopper. They were obtained at about $13 \mathrm{ft}$., $14 \mathrm{ft}$, and $15 \mathrm{ft} .6 \mathrm{in}$. respectively, from the surface.

From the same material I obtained small flakes and rudelychipped pieces, hammer-stones, and microliths. The majority seemed to be made from a different kind of flint from the three implements, and appeared to belong to the Chelles period. The pointed implement and the ovate were picked out with my fingers, and were seen by me lying in situ before I touched them. The latter lay flat. The chopper lay aslant, at about half a right angle. Ochreous sand adhered to the upper side, and the paler whitey-grey sand to its inner face. These bands practically alternated. The chopper plainly lay between two of them. The three implements are but little abraded. They are manifestly of one period. The stream which deposited the material must have done its work in a comparatively short time. Apparently, it had no more power than very occasionally to turn these implements over. The flints, quartzite pebbles, etc., constituting the thin gravel contained in the seams of sand were small. The three implements, together with some smaller specimens, are now in the British Museum. Mention is made of the microliths and of others from Knowle Farm Pit, in "Man," Vol. VIII., No. 7, p. 53.

The implements would probably be put down, at first sight, as of the Acheul I. period, and such, indeed, they may be. But, as knowledge progresses, sub-divisions of prehistoric time are found necessary. It is easy to carry it too far; at the same time, strongly suggestive evidence must not be dismissed in a single sentence. The considerations advanced in this paper are only thrown out as suggestions. The attention of other students to the facts adduced may shed clearer light on the matter.

There seems to be some reason for thinking that an industry, which has not yet received a name, closely succeeded Acheul I., but preceded Acheul II. ; and bore somewhat Moustier-like affinities. It may be that this industry was an early phase of Le Moustier. It is possible that this may be the cause of some French savants placing Le Moustier before Acheul I.

There are probably now a good many instances in which wellmade, unaltered implements have been found in England at about the same depth from the surface, and beneath the heavy clayey drift. The latter is widely spread in the South of England. It should be noted, in passing, that the stones in it, and especially in its upper part, are frequently to be seen standing up on end; whereas in the lower, stratified beds they lie flat. A cold period would seem to be indicated, following on the time of the deposition of the lower beds by perhaps fluviatile action. 
At Caddington, $550 \mathrm{ft}$. above O.D., Mr. Worthington Smith found that the Palæolithic floor beside an ancient chain of lakes and streams, and now beneath the contorted drift, sometimes reduplicated itself. The implements on the lower floor were grey and indigo; those on the upper one, white. The latter, both in colour and style, appear to agree with the French Acheul II. series. The former resemble the unaltered grey or black implements from other sites. The flat-faced type Mr. Worthington Smith declares to be characteristic of the lower floor. It so closely resembles the Le Moustier points, etc., that he regards the industry as belonging to that period. It is an important fact that these implements are found near the head waters of the rivers in the Chilterns at $550 \mathrm{ft}$. above O.D.; and that the Welwyn unaltered series were taken out from a similar stratigraphical position at $240 \mathrm{ft}$. above O.D., some nine miles down the valley in which the Mimram takes its rise. The arrangement of the beds at the two sites is similar, brick-earth being substituted at Caddington for the gravelly sands of Welwyn. At Caddington, as at Welwyn, the contorted drift above contains abraded implements of pre-Chelles, and, in the latter case, also of Chelles times. If the beds and the implements at the one site are of the same date as those of the other; or even if the Welwyn implements prove to be the earlier; we must then conclude that the valleys were already cut out to the greater part of their depth at the time that the Caddington men lived by their lakes, and ere the contorted drift covered up their abiding-place. Not only so, but probably the present sunken channels of the rivers were already carved out and filled with gravel. This would not be surprising, for boulder-clay filled the Lea valley at Hertford when it was already considerably excavated; and a large quantity of gravel obtained from the old channel of the river at that place contained nothing human that could be placed later than the Chelles period.

But where did the contorted drift on the hilltops at and near Caddington come from? Are we to conclude that whilst the Chiltern valleys were already cut out, higher land, to the $N$. of the present escarpment, had not yet been all denuded away? or that a greater depth of gravel, etc., covered the ridge in places and was swept into hollows and valleys during a cold period?

At Ware Road Pit, Hertford, I picked up one sharp, unaltered flake, sharply pointed at both ends, narrow, and having the bulb at the side. At Hertingfordbury two or three unabraded chipped flints were picked up. One good, sharp, black flake had evidently just fallen out of clay at the base of the heavy, red drift. The said clay is above the lowest, shingly gravel. At Hitchin, as Mr. Buller kindly informed me, two old land surfaces were found within the Hitchin gap. From the upper one implements only were found, worked on both faces. From the lower came flat-faced, unabraded implements and small flakes. Of two which were shown to me, one had parallel facets and a graver-like end; the other was sharply pointed, and might well belong to the Le Moustier period. A 
"side-chopper" in my possession has all the characteristics of that industry, and is black and unabraded.

The positions of the Levallois flakes from Swanscombe, and of Mr. Spurrell's discoveries, and of the High Lodge implements, all accord, I believe, with those from the above-mentioned sites, inasmuch as they were found below the level of the drift which contains derived implements of older periods.

A prolonged study of the material at Knowle Farm pit, Savernake, has shown it to be definitely stratified in places. At the top is river silt with a matrix of very fine sand; then comes contorted drift with a clayey matrix. All the strata contain derived implements. The tawny, stratified gravel at the base yields ovate Acheul I. implements. They are very slightly abraded, and in colour are green, red, etc. In the same gravel occur black and grey, unabraded and unaltered implements, etc. It cannot be said that their facies is either definitely Acheul I. or distinctly Le Moustier. There is some reason, however, for thinking that, in point of time, they are a little later than the Acheul $I$. implements. If this be the case, it is evident that they belong to a period between Acheul I. and II., the latter being found in the river silt at the top.

It is possible that there were, at this time, two races of men alternately making their appearance on certain sites. This might account for the differences of opinion among French savants as to the seniority of Acheul I. or Le Moustier.

If I am not mistaken in interpreting the evidence, it is plain that a sub-division is needed, and that the industry represented by the sharp black or grey implements from the sites treated of must either be regarded as Acheul I.B. or as a very early phase of Le Moustier. It must be admitted that many of the implements of this industry from Knowle Farm pit, as well as those from Welwyn, are worked on both faces. But this, I think, is to some degree true also of French Moustier sites. On the other hand, so far as colour goes, Acheul l. implements are usually green, red, yellow, etc., whereas the implements under consideration are black and grey. There was an inclination at this period, at Knowle Farm pit, to work for one curved cutting-edge only, and one or two implements are distinctly flat-faced. It is, besides, a noteworthy fact that many of the black Knowle implements resemble those of High Lodge, Mildenhall, and of some other Le Moustier sites in having an "untidy" base; i.e., the base is not neatly finished off, but is left in the boldly flaked, angular condition into which it was chipped in the blocking out of the flake or fragment, whilst the edge and upper end alone have been finely wrought.

In putting forward these suggestions, I desire that they should be treated as purely tentative as regards the particular stage to which the implements may be assigned; but I lay stress on the fact that, at Knowle Farm pit, at any rate, the industry certainly intervenes in point of time between Acheul I. and II. In suggesting the possibility (nothing more) of its being an early Moustier phase, I do not build on the mere fact of flat-faced implements being found, 
apart from style, etc.; for it cannot be too carefully remembered that this type of implement was introduced in very early times, long before the Moustier period, and continued almost all through the prehistoric ages.

\section{A DESCRIPTION OF THE SUB-CRAG DETRITUS-BED.} By AlFRED BeLL.

\section{Read at Norwich, March 23rd, 1915.}

The sub-Crag detritus-bed, sometimes called the nodule bed, or the Suffolk bone bed, was first brought to the notice of geologists by the late Prof. Henslow, who, in 1843, discovered that the Crag contained many nodules rich in lime phosphates, of great agricultural and commercial value-mostly known as "Coprolites," though not of coprolitic origin, unless the spirally-formed bodies are the coprolitic rejectamenta of sharks or other animals having a spiral intestine.

The detrital bed is principally made up of the following constituents :-(1) Phosphatic nodules (the so-called Coprolites). (2) Sandstone nodules or box-stones. (3) Rocks of various ages earlier than the Crag. (4) Large chalk flints, many unrolled. (5) Rolled and waterworn bones, usually much mineralised. (6) Cetacean beaks, and other bones. (7) Bones and teeth of land mammalia. (8) Wood and other items, chiefly of uncertain age.

The above groups are of very different periods, and I propose treating each one separately, their origin and mode of occurrence as far as is known, or suggested.

The groups are not of equal value numerically. Mr. Waller, one of, if not the largest, excavators in his day (1858) told Mr. S. V. Wood that the proportion of "Coprolites" to the flints was about 8 to 1 . The ratio varies in different localities, flints often occurring where coprolites are scarce or almost absent, as at the Dales (Bolton and Laughlin's brickyard), Back Hamlet, Ipswich, or Thorington Hall, Wherstead. Box-stones are also scarce here, but at Bawdsey they predominate.

The area covered by the detrital matter wholly or in part seems to have extended from Woodbridge to W. Ipswich, thence to Walton-on-the-Naze on one side, and to Boyton and Bawdsey on the other. How far it extended beyond this it is impossible to say ; a length of 10 to 12 miles is its longest diameter. The Crag has been traced with its flints and phosphates to Sudbury, and Monk's Eleigh, some miles away.

The detritus is most plentiful beneath the Waltonian and Newbournian zones of the Red Crag; workings below the earlier Coralline not having proved rich enough to be payable. Traces of 